\title{
Optimization of 'Nuruk', alcohol, and acetic acid fermentations for producing vinegar from Acorus gramineus roots
}

\author{
Na-Young Gil, Hee-Min Gwon, Soo-Hwan Yeo, So-Young Kim* \\ Fermented and Processed Food Science Division, Department of Agrofood Resources, \\ National Institute of Agricultural Sciences, RDA, Wanju 55365, Korea
}

\section{창포식초 생산을 위한 누룩, 알코올 및 초산발효 조건 최적화 \\ 길나영 · 권희민 · 여수환 · 김소영* \\ 농촌진흥청 국립농업과학원 농식품자원부 발효가공식품과}

\begin{abstract}
In this study, we investigated the quality characteristics of medicinal vinegar prepared from the roots of Acorus gramineus. We used barley alcohol beverage along with both Rhizopus oryzae 82-7 and Saccharomyces cerevisiae YM33 and vinegar culture with Acetobacter pasteurianus A11-2 under the optimal conditions for acetic acid fermentation. We manufactured the barley alcohol beverage with $11 \%$ alcohol content for fermentation with 'Nuruk' and Saccharomyces cerevisiae YM33 at $25^{\circ} \mathrm{C}$. When fermented vinegar from Acorus gramineus roots for 10 days at $30^{\circ} \mathrm{C}$ with a starter, the $\mathrm{pH}$ and total acidity were 3.48 and $4.44 \%$, respectively, and the alcohol in vinegar was totally consumed. Besides, the vinegar showed total polyphenol content of $870.13 \mathrm{mg}$ TAE $/ \mathrm{mL}$ at the $15^{\text {th }}$ day, along with significant antioxidant activity. GC-MS analysis revealed that the major volatiles in vinegar were methyl salicylate and 2-ethylhexanol, which have odors like those of mint and rose, respectively. In contrast, the ethanol, 3-methyl-1-butanol, and 2-methyl-1-propanol contents, which were high in the barley alcohol beverage, decreased in the vinegar that was fermented by Acorus gramineus. Consequently, the vinegar fermented by Acorus gramineus showed unique aromas and high antioxidant activity.
\end{abstract}

Key words : vinegar, Acorus gramineus, starter, volatiles

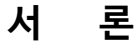

오랜 옛날부터 발효식초는 조리 시에 조미료로 사용할 뿐 만 아니라, 식품 방부제, 의약용으로도 다양하게 이용되어 왔 다. 식초는 크게 빙초산 또는 초산을 물로 희석하여 제조 한 합성 식초와 주류, 곡류, 과실류 등을 주원료로 하여 발효과정을 거쳐 제조한 발효식초로 나뉜다. 통상적으로 발효식초는 당이나 전분질을 함유하고 있는 원료가 효모 에 의해 당이 알코올로 발효되고, 다시 호기성 간균인 초산균
에 의해 알코올이 초산으로 산화되는 2 단계의 발효공정을 거 쳐 제조된다(Yim 등, 2015). 따라서 합성식초의 경우 유용성 분이 거의 없기 때문에 별다른 기능성이 없지만, 천연재료를 이용하여 자연 발효과정을 거쳐 제조하는 발효식초는 원료들 이 가지고 있는 고유 향기와 발효공정 중에 생성된 향기를 포함하고 있고, 초산 이외에 휘발성 및 비휘발성의 각종 유기 산류, 당류, 아미노산류, 에스테르류 등 각종 영양성분과 기 능성 물질 등이 포함되어 있다(Park 등, 2016). 식초는 매우 강한 살균력, 신맛을 보유하고 있어 식품가공 및 조리 시에

*Corresponding author. E-mail : foodksy@korea.kr, Phone : +82-63-238-3624, Fax : +82-63-238-3843

Received 15 September 2020; Revised 08 October 2020; Accepted 10 October 2020.

Copyright (c) The Korean Society of Food Preservation.

This is an Open Access article distributed under the terms of the Creative Commons Attribution Non-Commercial License (http://creativecommons.org/licenses/by-nc/4.0) which permits unrestricted non-commercial use, distribution, and reproduction in any medium, provided the original work is properly cited. 
다양한 목적으로 많이 활용되고 있고, 더불어 피로회복, 항비 만, 항종양, 항산화 등 다양한 생리활성도 보유하고 있다는 연구들이 다수 발표되고 있다(Cho 등, 2017; Mohamad 등, 2017; Sakanaka과 Ishihara, 2008). 최근에는 배식초(Park, 2016), 당근식초(Lee 등, 2016), 양파식초(Lee 등, 2017) 등 지역 농산물을 이용한 기능성 발효식초의 제품화 연구와 함 께 새로운 발효음료 시장이 형성되고 있는 추세이다.

창포(Acorus calamus L.)와 석창포(Acorus gramineus Soland)는 천남성과(天南星科, Acoraceae)에 속하는 다년생 식물로서 우리나라의 제주도, 황해도, 평북, 함남, 경북, 대구 등지와 중국의 호북, 호남, 사천성에 자생한다. 창포는 습지 에서 잘 자라 연못, 호수의 물가에 군생하며, 오염된 물에서는 자라지 않는다. 예로부터 지하 뿌리를 분말로 만들어 종기에 바르면 농즙을 빨아내는데 유효하고 단오절에 창포탕에 목욕 하면 사기를 없앤다고 하여 민간에서 이용하고 있으며, 동의 보감에는 창포 뿌리즙액을 찹쌀과 섞어 술을 빚어 상복하면 장수한다는 기록이 있다. 이와 같은 창포의 순기능과 관련하 여 창포 잎과 뿌리 중의 성분분석(Kim 등, 2000), 추출물의 아질산염 소거능과 tyrosinase 활성 저해 효과 등 생리활성 (Heo 등, 2008), 추출물의 모발 염색(Kim과 Baek, 2008), 모 발보호효과(Hwang, 2004) 등 이미용 소재 연구를 위한 선행 연구들은 다수 보고되어 있지만 석창포를 이용하여 식품에 적용한 연구논문은 그다지 많이 보고되어 있지 않다. 그러나 『산가요록(전순의, 1449)』, 『수운잡방(김유, 1540경)』, 『역주 방문(저자미상, 1800 대)』등 조선시대 고문헌에는 창포를 이 용한 식초 제조방법이 다수 수록되어 있다.

이에, 본 연구에서는 고문헌에 수록된 창포식초 제조방법 중 제조법 재현이 용이하고, 제시된 원료의 계량이 가능한 『역주방문』의 제법을 토대로 제한적 식품원료로 사용할 수 있는 석창포 뿌리를 이용하여 발효식초를 제조하는데 있어 서, 발효종균을 이용하여 누룩, 알코올 및 초산발효 조건을 최적화하여 창포식초를 제조하고, 그에 따른 이화학적 특성 을 조사하였다.

\section{재료 및 방법}

\section{실험재료 및 사용 균주}

본 실험에서 식초제조를 위해 사용한 석창포 뿌리(Acorus gramineus L.)는 국내산으로, 2018년 전주지역 로컬마켓에서 말린 것을 구매하였다. 누룩균은 Aspergillus niger 72-1 (KACC 93335P)과 Rhizopus oryzae 82-7(KACC 46960)의 2주, 알코올 발효를 위한 효모는 Saccharomyces cerevisiae $\mathrm{YM} 30$ 과 YM33(KACC 48334)의 2주을 각각 이용하였다. 식 초 제조를 위한 초산균(Acetobacter pasteurianus A11-2,
$\mathrm{KACC}$ 92203P)을 포함한 모든 균주는 국립농업과학원 발효 가공식품과에서 2010년부터 발효식품에서 발굴하여 한국농 업미생물은행(KACC, Jeonju, Korea)보관 중인 것을 사용하 였다.

\section{보리술 제조}

누룩균(A. niger 72-1, R. oryzae 82-7) 2주 중 누룩제조에 적합한 균주를 선발하기 위해 이들을 Potato Dextrose Agar (PDA, BD, Franklin Lakes, NJ, USA)에서 $30^{\circ} \mathrm{C}, 3$ 일간 배양 시켜 $5 \%$ 밀기울 배지에 다시 접종 $\left(1.0 \times 10^{6} \mathrm{CFU} / \mathrm{mL}, 1 \%\right)$ 하고 동일한 온도에서 5 일간 배양하였다. 그 다음 누룩 제조는 불리 고 증자한 보리에 각각 배양한 누룩균 중 포자를 회수, $10 \%$ 씩 접종하고 3 일간 $35^{\circ} \mathrm{C}$ 에서 발효하여 사용하였다(Fig. 1).

보리술 제조를 위해 알코올 생성능이 우수한 균주(data not shown)로 선발된 효모균(S. cerevisiae YM30, YM33) 2주 중, 보다 적합한 균주를 고르기 위해 Yeast extract Peptone Dextrose Agar(YPD Agar, BD, Franklin Lakes, NJ, USA)에 3 일간 $25^{\circ} \mathrm{C}$ 에서 배양시켜 형성된 단독 colony를 YPD broth (BD, Franklin Lakes, NJ, USA)에 접종, 배양 $\left(25^{\circ} \mathrm{C}, 72\right.$ 시간) 시켜 효모배양액으로 사용하였다. 이 효모배양액 $5 \mathrm{~mL}$ $\left(1 \times 10^{8} \mathrm{CFU} / \mathrm{g}\right)$ 에 불려 찐 쌀 $80 \mathrm{~g}$, 멸균수 $128 \mathrm{~mL}$ 를 첨가하 고, 3 일간 $30^{\circ} \mathrm{C}$ 에서 배양하여 주모를 제조하였다.

알코올 발효를 위해 보리쌀 $1 \mathrm{~kg}$ 을 불리고 60 분 동안 쪄 식힌 후 끓여 식힌 물 $1.8 \mathrm{~L}$, 누룩 $100 \mathrm{~g}$, 주모 $50 \mathrm{~mL}$ 를 넣어 잘 섞어 준 후 $25^{\circ} \mathrm{C}$ 에서 6 일간 정치 발효하여 보리술을 제조 하였다. 맑은 청주형 보리술을 얻기 위해 원심분리 $(8,000$ $\mathrm{rpm}, 5 \mathrm{~min}$ ) 후 여과지(Whatman No.2, London, England)로 여과하는 과정을 거쳐 시료액을 준비하였다.

\section{창포식초 제조}

초산균(A. pasteurianus A11-2)은 고체배지(yeast extract 5 $\mathrm{g} / \mathrm{L}$, glucose $50 \mathrm{~g} / \mathrm{L}, \mathrm{CaCO}_{3} 10 \mathrm{~g} / \mathrm{L}$, ethanol $30 \mathrm{~g} / \mathrm{L}$, agar $20 \mathrm{~g} / \mathrm{L}$ )에서 투명환을 나타내는 colony를 액체배지(yeast extract $5 \mathrm{~g} / \mathrm{L}$, glucose $5 \mathrm{~g} / \mathrm{L}$, glycerin $10 \mathrm{~g} / \mathrm{L}, \mathrm{MgSO}_{4} \cdot 7 \mathrm{H}_{2} \mathrm{O}$ $0.2 \mathrm{~g} / \mathrm{L}$, ethanol $60 \mathrm{~g} / \mathrm{L}$, acetic acid $10 \mathrm{~g} / \mathrm{L}$ )에 접종하여 3일 간 $30^{\circ} \mathrm{C}$ 에서 배양한 후 보리술을 탕수로 희석하여 알코올 농 도 6-8\% 범위로 제성한 후 5일씩 단계별 10 배씩 증량하며 3 회 배양하여 종초를 준비하였다.

초산발효는 『역주방문』의 제조법을 원형에 가깝게 복원하 기 위해 쌀 $200 \mathrm{~g}$ 을 수세 후 불려 절수한 후 분쇄한 쌀가루를 백설기떡 형태로 찌고 창포뿌리가루 $300 \mathrm{~g}$, 누룩 $500 \mathrm{~g}$, 보리 술(6-8\% 알코올) $1 \mathrm{~L}$, 종초 $200 \mathrm{~mL}(10 \%)$ 를 섞어 초산발효와 함께 알코올 발효가 진행되는 병행복발효 형태로 $30^{\circ} \mathrm{C}$ 에서 20 일 동안 발효시켰으며, 시료는 5 일 간격으로 채취하였다. 
(A)

\begin{tabular}{|c|c|c|c|}
\hline Ancient literature & Barley 'Nuruk' & Barley beverage & Acorus gramineus vinegar \\
\hline $\begin{array}{c}\text { Barley } \\
\qquad \downarrow\end{array}$ & Barley & Barley, water, 'Nuruk' & $\begin{array}{c}\text { Rice cake, Acorus gramineus, } \\
\text { 'Nuruk', barley beverage }\end{array}$ \\
\hline Soaking & $\downarrow$ & $\downarrow$ & $\downarrow$ \\
\hline$\downarrow$ & Soaking $(1 \mathrm{~h})$ & Barley wine starter & Vinegar starter (culture) \\
\hline Steaming & $\downarrow$ & $\downarrow$ & $\downarrow$ \\
\hline$\downarrow$ & Steaming \& Cool & Alcoholic fermentation & Acetic acid fermentation \\
\hline Alcoholic fermentation & $\downarrow$ & $\downarrow$ & $\downarrow$ \\
\hline (with water, 'Nuruk') & Inoculation of fungi & Filtration & Filtration \\
\hline Filtration & $\downarrow$ & $\downarrow$ & $\downarrow$ \\
\hline $\begin{array}{c}\downarrow \\
\text { Acetic acid fermentation } \\
\text { (with tice cake, Acorus gramineus, Nuruk') }\end{array}$ & Fermentation & $\begin{array}{l}\text { Alcohol content, } \\
\text { control (alcohol 7\%) }\end{array}$ & Maturation \\
\hline
\end{tabular}

Fig. 1. A flow chart of Acorus gramineus vinegar production between (A) reconstructed method from ancient literature and (B) improved method by starters (fungi, yeast and acetic acid bacteria).

\section{효소활성 측정}

제조 누룩의 효소활성 측정을 위해 누룩 $10 \mathrm{~g}$ 에 염화나트 륨 완충용액 $50 \mathrm{~mL}$ 를 가하고 실온에서 3시간 동안 자석교반 기(MSH-20D, DAIHAN Scientific Co., Ltd., Seoul, Korea) 를 이용하여 교반하여 침출한 후 여과한 것을 조효소액으로 이용하여 전분 분해능에 관여하는 $\alpha$-amylase, glucoamylase 의 효소활성을 정량적으로 분석하였다. 효소활성 측정은 Kikkoman(Noda, Japan)에서 생산한 주류분석용 효소키트에 제공되는 분석메뉴얼에 따라 진행하였으며, 각각의 효소액을 분광광도계(UV-2450, Shimadzu, Kyoto, Japan)를 이용하여 $400 \mathrm{~nm}$ 에서 정량적으로 측정하였다.

\section{알코올 및 당도 측정}

보리술의 알코올 함량 분석은 알코올증류기(Vapodest 200 , Gerhardt GmbH, Konigswinter, Germany)를 이용하여 증류액 $70 \mathrm{~mL}$ 에 증류수를 첨가하여 $100 \mathrm{~mL}$ 로 정용한 후 밀 도 측정기(DMA 5000M, Anton Paar, Graz, Austria)를 이용 하여 분석하였다. 그리고 보리술의 당도는 여과액의 일정량 을 굴절당도계(Pocket Refractometer PAL-1, ATAGO Co., Tokyo, Japan)를 이용하여 실온에서 측정하였다.

\section{$\mathrm{pH}$ 및 산도 측정}

창포식초의 발효기간별 품질특성 변화를 조사하기 위해 $\mathrm{pH}$ 는 여과한 시료액을 $\mathrm{pH}$ meter(Orion 3 star, Thermo Fisher
Scientific Inc., Waltham, MA, USA)를 이용하여 측정하였고, 산도는 시료액 $1 \mathrm{~mL}$ 를 취하여 $0.1 \mathrm{~N} \mathrm{NaOH}$ 를 이용하여 중화 적정 $(\mathrm{pH}$ 8.3)하였으며, 소비된 용액의 양을 acetic $\operatorname{acid}(\%)$ 로 환산하여 계산하였다.

\section{총폴리페놀 함량 분석}

총폴리페놀 함량 측정을 위해 창포식초 시료액 $250 \mu \mathrm{L}$ 에 $2 \mathrm{~N}$ Folin-Ciocalteu phenol reagent $1 \mathrm{~mL}$ 를 첨가한 후 3 분 동안 암실에 방치하고, $0.1 \mathrm{~N} \mathrm{Na}_{2} \mathrm{CO}_{3} 2 \mathrm{~mL}$ 를 넣어 60 분 간 암실에 둔 후 분광광도계로 $765 \mathrm{~nm}$ 파장에서 흡광도를 측정 하였다. 표준물질로 tannic acid(Sigma Chemical Co., St. Louis, MO, USA)를 이용하여 작성한 표준곡선을 바탕으로 환산하여 그 함량(TAE $/ \mathrm{mL}$, tannic acid equivalent)을 나타내 었다.

\section{항산화능 측정}

창포식초의 항산화능은 1,1-diphenyl-2-picryl hydrazyl $(\mathrm{DPPH})$ 과 $\mathrm{ABTS}$ radical의 소거 활성 측정을 통해 분석하였 다. DPPH radical 소거 활성(\%)은 희석한 시료액 $0.2 \mathrm{~mL}$ 에 $1.5 \mathrm{mM} \mathrm{DPPH}$ 용액 $0.8 \mathrm{~mL}$ 를 넣고 30 분간 암실에 방치한 후 분광광도계로 $517 \mathrm{~nm}$ 파장에서 흡광도를 측정하였다. ABTS radical 소거율(\%)은 희석한 시료액 $50 \mu \mathrm{L}$ 에 $7 \mathrm{mM}$ 2,2'-azinobis-(3-ethylbenzothiazoline-6-sulphonic acid(ABTS)와 $2.45 \mathrm{mM}$ potassium persulfate를 혼합한 혼합 
액 $950 \mu \mathrm{L}$ 를 실온에서 10 분간 반응시켜 $735 \mathrm{~nm}$ 파장에서 분광광도계로 흡광도를 측정하였다. Radical 소거능은 아래 식에 측정된 흡광도 값을 대입하여 산출하였다.

라디칼 소거 활성 $(\%)$

$=(1-$ 시료군 흡광도 / 대조군 흡광도 $) \times 100$

\section{향기성분 분석}

보리술과 창포식초의 향기성분 변화를 살펴보기 위해 전 문분석기관인 (주)이지메스에 의뢰하여 GC-2010 Plus와 GCTQ-MS 8030(Shimazu, Tokyo, Japan)을 이용하여 분석하였 다. 식초 원액을 증류수로 4 배 희석한 $500 \mu \mathrm{L}$ 와 $\mathrm{NaCl} 1 \mathrm{~g}$, 증류수 $1.5 \mathrm{~mL}$ 를 vial에 넣어 $25^{\circ} \mathrm{C}$ 에서 30 분 동안 교반한 후 solid phase microextraction(SPME)에 5분 동안 흡착시켜 주 입하였다. GC column(DB-WAX column, $30 \mathrm{~m} \times 0.25 \mathrm{~mm}$ id, $0.25 \mu \mathrm{m}$ film thickness; J \& W scientific, Santa Clara, CA, USA), injection temp $\left(250^{\circ} \mathrm{C}\right)$, column flow $(1 \mathrm{~mL} / \mathrm{min})$, carrier gas(Helium)의 조건에서 오븐온도를 $40^{\circ} \mathrm{C}$ 에서 3 분간 유지한 다음 분당 $5^{\circ} \mathrm{C}$ 씩 $90^{\circ} \mathrm{C}$ 까지 승온시킨 후 분당 $19^{\circ} \mathrm{C}$ 씩 $230^{\circ} \mathrm{C}$ 까지 승온시켜 5 분간 머물렀다. MS 조건은 Q3 scan mode에서 ion source temperature $\left(230^{\circ} \mathrm{C}\right)$, interface temperature $\left(280^{\circ} \mathrm{C}\right)$, detector voltage $(0.1 \mathrm{kV})$, event time $(0.03 \mathrm{~s}$, $15 \mathrm{ev)}$ 의 조건으로 진행하였다.

\section{통계 분석}

모든 실험은 3 회 반복 측정하였고, 결과는 평균값 \pm 표준편 차로 나타내었다. 각 실험구 간의 유의성 $(\mathrm{p}<0.05)$ 검증을 위 해 통계적 분석은 SAS(Statistical Analysis System program, SAS Institute, Cary, NC, USA)와 xlstat 프로그램을 이용하 여 분산분석(analysis of variance, ANOVA)한 후 Duncan's multiple range test로 다중비교를 실시하였다.

\section{결과 및 고찰}

\section{보리술 제조를 위한 균주선발 및 발효특성 조사}

창포식초에 사용되는 보리술을 제조하기 위해 국립농업과 학원 발효가공식품과에서 발굴하고 보유하고 있는 누룩균과 효모균들 중에서 보리술 제조에 보다 적합한 균주를 선발하 기 위해 높은 당화력을 가지는 Aspergillus niger 72-1와 Rhizopus oryzae 82-7 등 2주의 누룩균을 이용하여 보리누룩을 제조하였고, 알코올 생성능을 가진 Saccharomyces cerevisiae $\mathrm{YM} 30$ 와 YM33 등 효모 2주를 접종한 주모를 이용하여 보리 술을 제조하였다. 제조한 누룩은 효소활성을, 보리술의 경우 는 알코올 생성능을 비교분석하였고, 그 결과를 Fig. 2에 제
시하였다.

먼저 곰팡이 2 주를 이용하여 제조한 입국형태의 보리누룩 은 3 일간 발효시킨 후 $\alpha$-amylase와 gluco-amylase 등 효소활 성을 측정하였다. 그 결과, 두 시료 모두 통계적 유의성이 있 게 높은 활성을 보였다 $(\mathrm{p}<0.05)$. 특히 $R$. oryzae 82-7를 접종 하여 제조한 누룩의 경우 alpha-amylase는 $26.99 \mathrm{unit} / \mathrm{g}$, gluco-amylase 122.06 unit $/ \mathrm{g}$ 으로 A. niger 72-1보다 높은 활 성을 나타내었다(Fig. 2A). Choi 등(2016)의 보고에 따르면 곰팡이를 이용하여 제조한 누룩의 효소활성을 비교해본 결과,

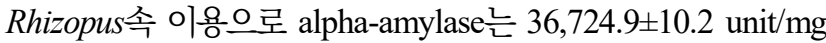
protein, gluco-amylase는 4,911.8 $\pm 48.1 \mathrm{SP}$ 로 Aspergillus 속을 이용한 것보다 약 2.65배, 15.21 배 높은 효소활성을 나타내어 본 연구결과와 유사한 경향을 보였는데, 이와 같은 결과는 Rhizopus속이 생전분을 분해하는 활성이 높고, 균주별 배양 재료들의 영양요구성 차이로 인해 나타난 결과로 판단된다고 언급하고 있다. 이에 높은 전분분해 효소활성을 나타낸 $R$. oryzae 82-7을 이용하여 제조한 누룩으로 보리술을 만들었다.

Fig. 2B에 나타낸 바와 같이 알코올 발효를 위해 $S$. cerevisiae $\mathrm{YM} 30$ 과 $\mathrm{YM} 33$ 의 효모2균주를 보리술 제조에 사 용한 후 일정한 발효기간 동안 알코올 함량 변화를 살펴보았 다. 그 결과, S. cerevisiae $\mathrm{YM} 33$ 균주를 접종한 후 $25^{\circ} \mathrm{C}$ 에서 6 일간 발효시켰을 때 알코올 함량이 $10.73 \%$ 로 유의적으로 가장 높은 값을 나타내었고( $\mathrm{p}<0.05)$, 당도는 효모 무처리군, $\mathrm{YM} 30$, 그리고 YM33 처리군 순으로 낮아져 알코올 발효에 따른 당이 소비되었음을 확인할 수 있었다. 따라서 최종적으 로 높은 당화력을 보유한 R. oryzae 82-7 균주로 제조한 누룩 과 높은 알코올 생성능을 보여준 S. cerevisiae YM33 균주를 종균으로 이용하여 보리술 제조공정의 최적화 조건을 살펴보 았다.

\section{발효온도에 따른 보리술의 제조조건 확립}

Rhizopus oryzae 82-7 균주를 이용하여 제조한 보리누룩과 S. cerevisiae YM33 균주를 이용하여 보리술을 제조함에 있 어 발효온도, 기간 등 최적 발효 조건을 확립하기 위해 알코올 함량 및 당도 변화를 분석하여 결과를 Table 1에 제시하였다.

먼저 발효온도에 따른 알코올 함량 변화를 살펴본 결과, 발 효가 진행됨에 따라 그 함량이 증가하였고, 발효 9일 차에는 발효온도 25 와 $30^{\circ} \mathrm{C}$ 에서 각각 $11.0 \pm 0.0$ 과 $11.2 \pm 0.0 \%$ 의 알코 올 함량을 나타내었고, $20^{\circ} \mathrm{C}$ 에서는 $9.7 \pm 0.0 \%$ 로 다소 낮은 함 량이 검출되었다. Han 등(1997)과 Baek 등(2015)이 보고한 누룩 종류를 달리한 탁주 술덧과 주모용 S. cerevisiae를 사용 하여 제조한 탁주 술덧의 마지막 단계에서 생성된 알코올 함 량이 각각 $8.2-12.6 \%$ 와 7.2-8.5\%로 이번 연구결과보다 조금 낮은 값을 나타내었다. 이와 같은 알코올 생성능 차이는 사용 
(A)
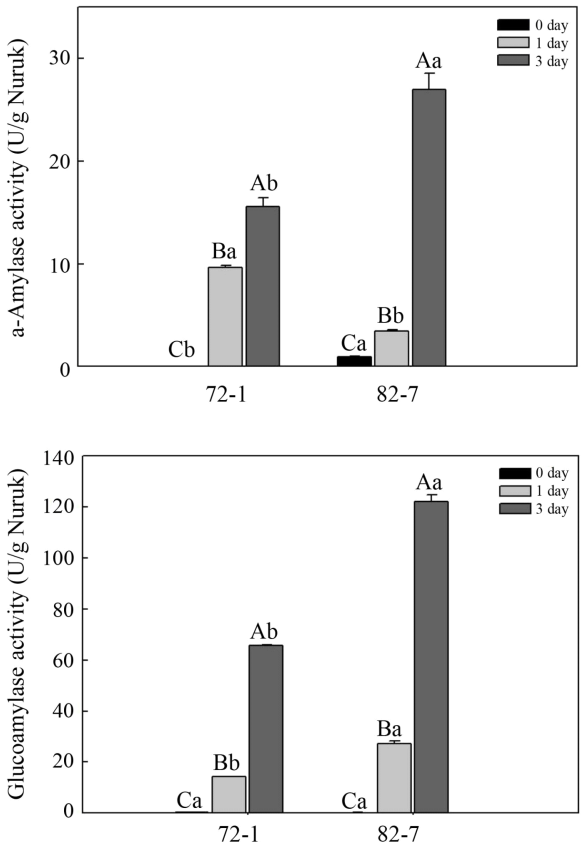

(B)
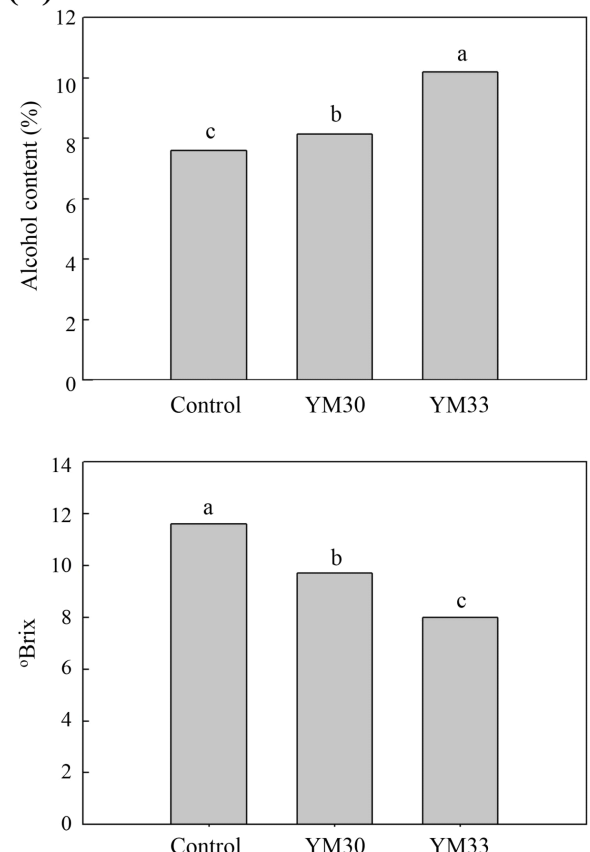

Fig. 2. Comparison of enzyme activities, alcohol and sugar contents of barley 'Nuruk' and beverage cultivated by different strains. A, enzyme activity of barley 'Nuruk' fermented by different mold for 3 days; B, physiochemical components of barley beverage fermented by different yeasts for 6 days

72-1, Aspergillus niger; 82-7, Rhizopus oryzae; Control, non-treated yeast; YM30 and YM33, Saccharomyces cerevisiae.

Any means in the same fermentation time ${ }^{A-C}$ ) or strains $\left({ }^{a, b}\right)$ followed by different letters are significantly different by Duncan's multiple range test $(\mathrm{p}<0.05)$.

Table 1. Physiochemical components of alcohol beverage according to fermentation temperature and Acorus gramineus vinegar fermented by acetic acid bacteria

\begin{tabular}{|c|c|c|c|c|c|}
\hline Group ${ }^{1)}$ & Period (day) & $\mathrm{pH}$ & Titratable acidity (\%) & Alcohol (\%) & ${ }^{\circ}$ Brix \\
\hline \multicolumn{6}{|l|}{ Alcohol beverage } \\
\hline $20^{\circ} \mathrm{C}$ & 9 & $\mathrm{NA}^{2)}$ & NA & $9.72 \pm 0.00^{\mathrm{C}}$ & $8.00 \pm 0.00^{\mathrm{B}}$ \\
\hline $25^{\circ} \mathrm{C}$ & 9 & NA & NA & $11.00 \pm 0.00^{\mathrm{B}}$ & $7.80 \pm 0.00^{\mathrm{C}}$ \\
\hline $30^{\circ} \mathrm{C}$ & 9 & NA & NA & $11.20 \pm 0.00^{\mathrm{A}}$ & $11.10 \pm 0.00^{\mathrm{A}}$ \\
\hline \multicolumn{6}{|l|}{ Vinegar $30^{\circ} \mathrm{C}$} \\
\hline \multirow[t]{3}{*}{ Control } & 10 & $4.03 \pm 0.00^{\mathrm{A} 3 \mathrm{c} 4)}$ & $0.94 \pm 0.01^{\mathrm{Bb}}$ & $3.10 \pm 0.14^{\mathrm{Ab}}$ & NA \\
\hline & 15 & $4.10 \pm 0.00^{\mathrm{Aa}}$ & $0.94 \pm 0.03^{\mathrm{Bb}}$ & $2.50 \pm 0.14^{\mathrm{Ac}}$ & NA \\
\hline & 20 & $4.07 \pm 0.00^{\mathrm{Ab}}$ & $1.05 \pm 0.01^{\mathrm{Ba}}$ & $3.68 \pm 0.00^{\mathrm{Aa}}$ & NA \\
\hline \multirow[t]{3}{*}{ A11-2 } & 10 & $3.48 \pm 0.00^{\mathrm{Bc}}$ & $4.44 \pm 0.03^{\mathrm{Aa}}$ & $0.00 \pm 0.00^{\mathrm{Ba}}$ & NA \\
\hline & 15 & $3.54 \pm 0.00^{\mathrm{Bb}}$ & $4.19 \pm 0.08^{\mathrm{Ab}}$ & $0.00 \pm 0.00^{\mathrm{Ba}}$ & NA \\
\hline & 20 & $3.62 \pm 0.00^{\mathrm{Ba}}$ & $4.10 \pm 0.06^{\mathrm{Ab}}$ & $0.00 \pm 0.00^{\mathrm{Ba}}$ & NA \\
\hline
\end{tabular}

${ }^{1)}$ Control, non-treated; A11-2, Acorus gramineus vinegar of fermented by Acetobacter pasteurianus.

2) NA, not available.

${ }^{3)}$ Any means in the same fermentation time $\left({ }^{\mathrm{A}-\mathrm{B}}\right)$ followed by different letters are significantly different by Duncan's multiple range test $(\mathrm{p}<0.05)$.

${ }^{4)}$ Any means in the same fermentation time $\left({ }^{\mathrm{A}-\mathrm{B}}\right)$ or strains $\left({ }^{\mathrm{a}-\mathrm{c}}\right)$ followed by different letters are significantly different by Duncan's multiple range test $(\mathrm{p}<0.05)$. 
한 균주의 발효특성과 쌀과 함께 사용한 보리쌀의 원료에 따 른 차이로 보이는데, Hwang(2002)에 의한 연구결과에서 쌀, 찹쌀, 보리쌀을 혼용한 탁주에서 알코올 함량은 $11 \%$ 로 가장 높았고, 쌀, 보리쌀만 혼용한 경우 $10.4 \%$ 로 쌀 또는 찹쌀을 사용하여 제조한 탁주보다 높은 알코올 함량을 나타내어 본 연구결과와 유사한 경향을 보였다. 한편, 보리술의 당도 변화 를 살펴본 결과, 9 일 간의 발효기간 동안 각각의 발효온도에 서 모든 시료들이 발효가 진행됨에 따라 점차 증가하였고, 발 효초기에 $3.0 \pm 0.0{ }^{\circ} \mathrm{Brix}$ 에서 20 과 $25^{\circ} \mathrm{C}$ 에서는 $8.0 \pm 0.0$ 과 $7.8 \pm 0.0^{\circ} \mathrm{Brix}$ 이었고, $30^{\circ} \mathrm{C}$ 에서는 $11.1 \pm 0.0{ }^{\circ} \mathrm{Brix}$ 로 높은 값 을 나타내었다. 이는 발효 초기보다 보리술 내 전분가수분해 가 활발히 진행되어 당도가 높아졌다가, 알코올 생성 관련 효 모의 작용으로 당 소비가 일어난 것으로 사료된다.

따라서 다른 미생물들이 이용할 수 있는 당 함량은 낮고 알코올 생성량이 높았던 $25^{\circ} \mathrm{C}$ 에서 9 일간 발효시킨 보리술을 창포식초 제조 시 사용하였다.

\section{종초 이용 창포식초의 최적 발효조건 확립}

선행연구를 통해 발굴된 산생성능이 우수한 $A$. pesteurianus A11-2 초산균(Gil 등, 2020)을 보리술에 적용하여 창포식초 제조를 위한 최적 발효조건을 확립하기 위하여 발효기간별 $\mathrm{pH}$, 산도 및 알코올 함량 변화를 살펴보았다(Table 1). 창포 식초는 찐 쌀, 창포뿌리가루, 누룩 등 사용하는 원료 및 배합 비율의 특징에 따라 고상발효로 진행되어 초기 발효에는 시 료액 채취가 어려워 미생물에 의한 가수분해 작용이 원활해 지는 발효 10 일 차부터 시료를 채취하여 품질분석을 실시하 였다.

먼저 창포식초 중 $\mathrm{pH}$ 는 A. pesteurianus $\mathrm{A} 11-2$ 를 이용하 여 제조한 종초를 넣은 실험구의 경우 발효 10 일 차에 3.48 에 서 20 일 차에 3.62 로 낮은 $\mathrm{pH}$ 를 보인 반면, 종초를 사용하지 않은 시료(대조구)의 경우 조금 높은 4.03-4.10 범위 내 값을 나타내었다. 산도는 종초를 넣은 실험구의 경우, 발효 10 일 차 시료에서 $4.44 \pm 0.03 \%$ 로 가장 높은 값을 나타내었고, 이후 발효가 진행됨에 따라 유의적으로 약간 감소하는 경향을 보 였는데 $(\mathrm{p}<0.05)$, 초산발효가 종료되고 난 후 초산균에 의한 초산을 분해하는 과산화 작용으로 이산화탄소가 생성되어 발 생한 것이라 사료된다(Baek 등, 2013). 이에 반해, 종초를 넣 지 않은 대조구의 경우 발효 10 일 차에 $0.94 \pm 0.01 \%$ 에서 20 일 차에 $1.05 \pm 0.01 \%$ 로 그다지 큰 변화를 나타내지 않아 초산 발효가 원활하게 이루어지지 않았음을 알 수 있었다. 알코올 함량은 종초를 넣은 실험구는 발효 10 일 차에 이미 검출되지 않아 초산발효가 완료되었고, 종초를 넣지 않은 대조구의 경 우 발효 10 일 차에 $3.10 \pm 0.14 \%$ 에서 발효 20 일 차에 $3.68 \pm$ $0.00 \%$ 로 거의 변화가 없어 초산 발효가 거의 일어나지는 않
았지만, 발효 15 일 차에 $2.4 \pm 0.14 \%$ 로 낮아졌다가 발효 20 일 차에 알코올 함량이 다소 높아져 식초 제조 시 첨가한 쌀가루 로 만든 백설기떡에 보리누룩를 사용함으로 초산발효와 함께 알코올 발효가 진행되는 병행복발효로 인해 알코올 함량이 약간 높아진 것으로 사료된다. Cho 등(2000)에 따르면 병행 복발효의 경우 혐기적 조건에서 효모에 의한 알코올발효와 호기적 조건에서 초산균에 의한 초산발효가 동시에 이루어지 는 방식으로 종초를 넣지 않은 대조구의 경우 알코올과 초산 생성이 경미하게나마 증가하여 병행복발효 현상이 나타난 것 으로 사료된다.

이번 연구 결과를 통해 종초를 이용하여 제조한 창포식초 의 경우 초산발효 과정 중 초산균이 알코올을 영양원이나 발 효 기질로 사용하여 초산을 포함한 유기산을 생성시켜 산도 를 높이지만, 종초를 이용하지 않고 식초를 제조하는 경우 첨 가된 곡류와 누룩으로 인해 알코올 생성에 영향을 주어 초산 발효가 원활하게 일어나지 않게 됨을 알 수 있었다. 이에 창 포식초 제조 시 A. pesteurianus와 같은 초산균 함유 종초 사 용으로 발효기간 단축과 산 생산성에 있어 큰 강점을 가질 수 있을 것으로 사료된다.

\section{창포식초의 총폴리페놀 함량 및 항산화능}

선정된 곰팡이, 효모, 그리고 초산균을 이용하여 최적화된 조건에서 창포뿌리를 이용하여 제조한 식초의 총폴리페놀 함 량과 항산화능을 측정하여 그 결과를 Fig. 3에 나타내었다. 종초 첨가 창포식초 중 함유된 총폴리페놀 함량은 발효 15 일 차에 $870.13 \mathrm{mg} \mathrm{TAE} / \mathrm{mL}$ 로 가장 높은 값을 나타내었고, $\mathrm{DPPH}$ radical 및 $\mathrm{ABTS}^{+}$radical 소거 활성도 종초 무첨가 식초인 대조구와 비교하여 종초 첨가 실험구에서 유의적으로 높게 나타났다 $(\mathrm{p}<0.05)$. 특히 DPPH radical 소거 활성 측정 결과, 종초 무첨가 대조구의 경우 발효가 진행됨에 따라 감소 하였지만 종초 첨가 실험구의 경우 15 일 차에 감소하였고, 20 일 차에 증가하여 가장 높은 값을 나타내었다. 하지만, $\mathrm{ABTS}^{+}$radical 소거 활성의 경우 발효가 진행되면서 약간 증 가하는 경향을 보인 종초 첨가 실험구는 발효되면서 그다지 큰 변화를 보이지 않았던 종초 무첨가 대조구와 비슷한 값을 나타내어 뚜렷한 차이를 보이지 않았다.

Jung 등(2007)에 따르면 창포의 총폴리페놀 함량이 249.1 $\mu \mathrm{g} / \mathrm{mL}$ 로 높은 값을 나타내었고, 4종류의 창포 항산화능을 비 교 연구한 결과에서는 $125 \mu \mathrm{g} / \mathrm{mL}$ 의 농도에서 $23.09-41.79 \%$ 의 DPPH radical 소거능과 46.76-92.47\%의 ABTS radical 소거 능을 보여 본 연구와 같은 높은 항산화능을 보였다(Choi 등, 2011). Lee 등(2014)의 으름 열매식초 연구에서는 발효가 진 행되는 동안 라디칼 소거능이 유의적으로 증가하여 초산 발 효로 인해 항산화능이 증가하여 종초 무첨가군에서는 증가하 

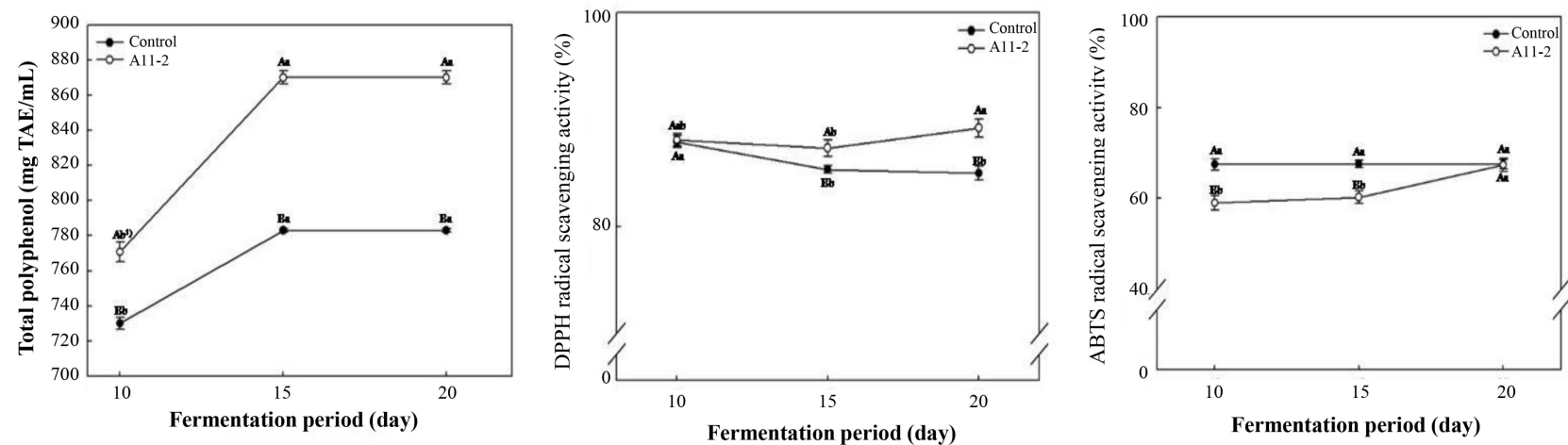

Fig. 3. Total polyphenol content and antioxidant activity of Acorus gramineus vinegar fermented by acetic acid bacteria.

Any means in the same fermentation time (A-B) or strains (a-d) followed by different letters are significantly different by Duncan's multiple range test $(\mathrm{p}<0.05)$.

지 않은 항산화능이 종초 첨가구에서는 증가한 본 연구와 일 부 유사한 경향을 보였다. 이는 Pang 등 (2008)이 보고한 창 포에 함유되어 있는 $\alpha$ - 그리고 $\beta$-asarone과 같은 유효성분이 식초 제조 과정에서 추출되어 그에 따른 항산화능 효과를 나 타낸 것으로 사료된다.

\section{창포식초의 향기성분}

발효기간에 따른 창포식초의 향기성분 변화를 보리술과
함께 비교 분석하여 Table 2 및 Fig. 4에 나타내었다. 먼저 창포식초 제조를 위해 만든 보리술의 경우, 주성분인 ethanol 이 $25^{\circ} \mathrm{C}$ 온도에서 9 일간 발효하였을 때 $12.22 \%$ 로 가장 높게 검출되었고, 그 다음으로 위스키, 탄향을 특징으로 하는 3-methyl-1-butanol이 8.72\%, 달콤하고 고급스러운 나무향을 가지는 methyl salicylate가 $5.1 \%$ 순으로 높게 검출되었다. 그 외에도 자극적인 향인 acetic acid, ethyl ester가 $3.41 \%$, 달콤 한 향을 가지는 2-methyl-1-propanol $1.29 \%$, 장미향 또는 풀

Table 2. Volatile components in barley beverage and Acorus gramineus vinegar

\begin{tabular}{|c|c|c|c|c|c|c|c|}
\hline \multirow{2}{*}{ Compound } & \multirow{2}{*}{ Odor description ${ }^{1)}$} & \multicolumn{3}{|c|}{$\begin{array}{l}\text { Alcohol beverage according } \\
\text { to fermented temperature }\left({ }^{\circ} \mathrm{C}\right)\end{array}$} & \multicolumn{3}{|c|}{$\begin{array}{l}\text { Acorus gramineus vinegar } \\
\text { according to fermented period (day) }\end{array}$} \\
\hline & & 20 & 25 & 30 & 0 & 10 & 15 \\
\hline Acetic acid, ethyl ester & Ethereal, fruity & 3.39 & 3.41 & 1.99 & 0.60 & 1.26 & 2.43 \\
\hline Ethanol & Sweet & 10.72 & 12.22 & 11.36 & 2.80 & 0.00 & 0.51 \\
\hline 2-Methyl-1-propanol & Sweet & 1.09 & 1.29 & 0.77 & 0.20 & 0.00 & 0.03 \\
\hline 3-Methyl-1-butanol, acetate & Banana & 0.27 & 0.43 & 0.17 & 0.00 & 0.00 & 0.07 \\
\hline 3-Methyl-1-butanol & Whiskey, malt, burnt & 7.73 & 8.72 & 5.75 & 1.62 & 0.39 & 0.28 \\
\hline 4-Methyl-2-heptanone & Unknown & 0.07 & 0.10 & 0.07 & 0.08 & 0.15 & 0.10 \\
\hline 1-Limonene & Orange & 0.09 & 0.29 & 0.21 & 0.46 & 0.40 & 0.21 \\
\hline Octanal & Fat, soap, lemon, green & 0.07 & 0.16 & 0.07 & 0.22 & 0.15 & 0.17 \\
\hline 2-Methyl-2-octanol & Spicy & 0.11 & 0.12 & 0.13 & 0.05 & 0.05 & 0.05 \\
\hline Nonanal & Rose-orange & 0.49 & 1.22 & 0.49 & 1.09 & 0.72 & 0.86 \\
\hline 2-Ethylhexanol & Rose, green & 2.13 & 1.68 & 2.03 & 1.41 & 1.93 & 1.92 \\
\hline Decanal & Soap, orange peel, tallow & 0.22 & 0.14 & 0.15 & 0.28 & 0.19 & 0.38 \\
\hline Methyl salicylate & Peppermint & 3.64 & 5.10 & 5.00 & 5.81 & 9.48 & 7.91 \\
\hline
\end{tabular}

${ }^{1)}$ Odorant referred from PubChem (http://pubchem.ncbi.nlm.nih.gov) and Wikipedia (http://ko.wikipedia.org) database. 


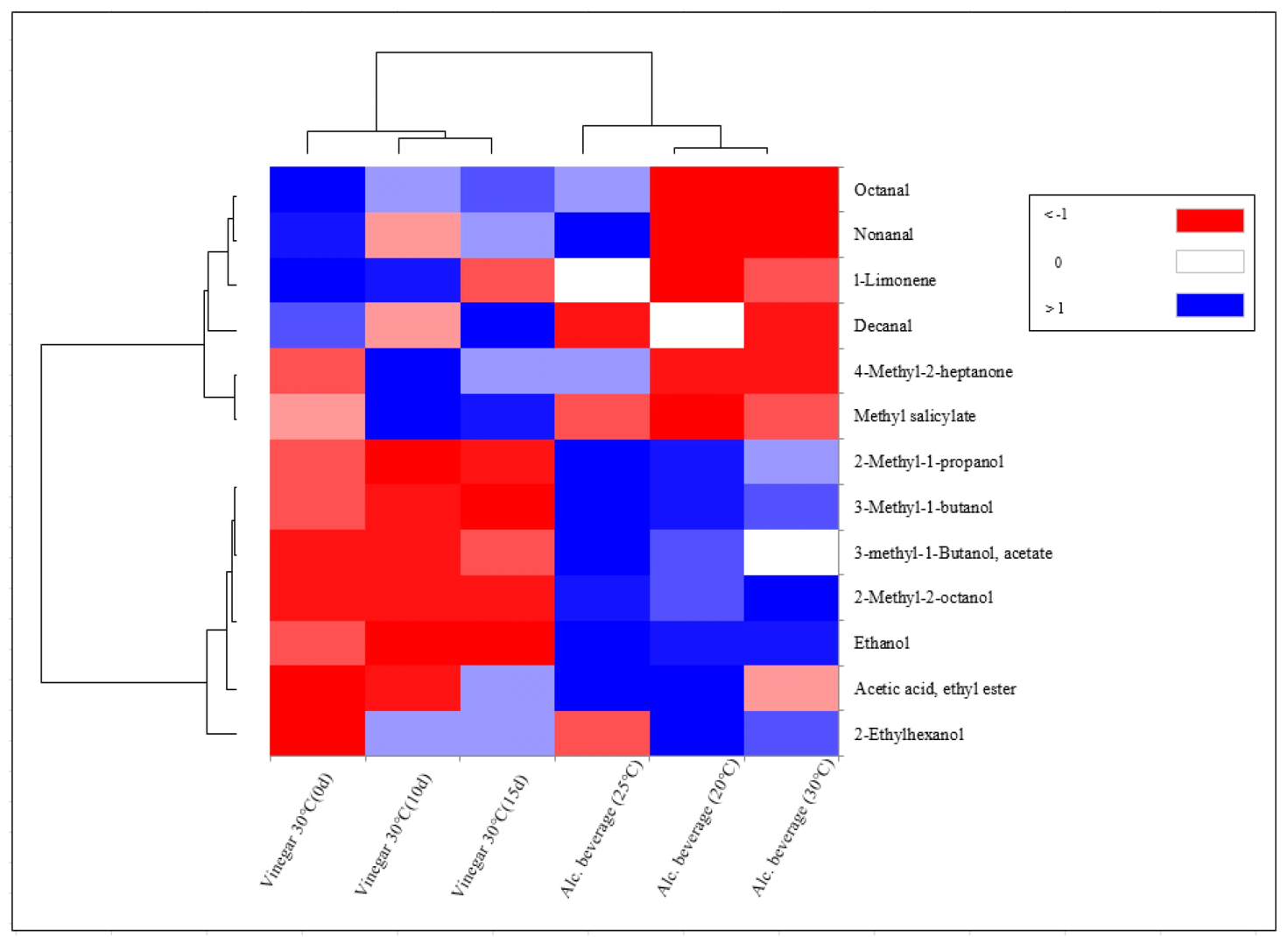

Fig. 4. Heatmap of volatile aroma compounds identified in barely alcohol beverage and Acorus gramineus vinegar during fermentation.

향을 나타내는 2-ethylhexanol $1.68 \%$ 등 다양한 향기성분이 검출되었다.

반면, 창포식초 내 향기성분 중 보리술에 높게 검출되었던 알코올은 $0.51 \%$ 로 낮게 나타났는데, acetic acid, ethyl ester 또한 $2.43 \%$ 로 낮게 검출되었다. 무엇보다 가장 높은 함량을 나타낸 것은 고급스러운 민트향을 가지는 methyl salicylate 로 $7.91 \%$ 의 높은 함량을 나타냈고, 달콤한 꽃향기를 내는 2-ethylhexanol이 $1.92 \%$ 로 미미하지만 methyl salicylate와 함께 보리술보다 높게 검출되었다. Fig. 4의 heatmap 분석을 통해 나타낸 결과에서는 발효가 진행되면서 acetic acid, ethyl ester와 2-ethylhexanol, mehtyl salicylate는 증가하였지 만 레몬, 오렌지, 페퍼민트 등 달콤하고 상큼한 향을 나타내 는 octanal, nonanal, 1-limonene, decanal 등 향기성분은 발효 초기부터 높아 기간에 따른 뚜렷한 차이를 나타내지는 않았 지만, 보리술에 비해서는 창포식초에서 조금 높게 검출되어, 이들 향기성분들에 의해 창포식초가 특징지어질 수 있을 것 으로 판단된다. Choi(2005)에 따르면 GC/olfactometry 분석 을 통해 창포뿌리 오일에는 주로 cis, trans-farnesol, octanoic acid, trans-2-dodecenal 등 향기성분이 포함되어 있다고 보고 하였지만, 본 연구에서 GC-MS를 이용하여 분석한 창포식초
에서는 이와 같은 향기성분은 검출되지 않았다.

식초는 초산 발효과정에서 각 휘발성 향기 성분이 다른 정 도로 증발하기 때문에 향기 성분은 다양하게 변화하는 것으 로 알려져 있어 보리술보다 식초에서 단순한 향기성분을 보 인 것으로 사료된다(Chen, 2013). 아울러 창포식초는 보리술 이 가지고 있는 ethanol, 3-methyl-1-butanol 등 향은 감소되 고, 민트향을 내는 methyl salicylate(Danner 등, 2011)를 주 로 하는 향기성분과 오렌지, 레몬 등 상큼한 향을 갖는 성분 들은 증가하여 이를 특징으로 하면서 발효종균을 사용하여 고문헌에서 복원한 새로운 발효식초로서 제조방법이 최적화 되었다. 하지만 창포식초를 이미용 제품 외 음용을 위한 식품 제조 시에는 식품위생법에 제시된 기준에 준하여야 하면 $\alpha$-, $\beta-, \lambda$-asarone 등 독성물질들의 함유 여부를 반드시 검증한 후 제품화하여야 한다.

\section{요 약}

본 연구에서는 『역주방문』에 소개된 창포식초 제조방법을 발효종균을 이용하여 누룩, 알코올 및 초산발효 조건을 최적 화하여 발효식초를 제조하고, 그에 따른 품질특성 변화를 살 
펴보았다. 누룩은 alpha-amylase, gluco-amylase 등 효소활성 이 높은 Rhizopus oryzae 82-7 균주를 증자한 보리쌀에 접종 하여 입국 형태로 제조하였고, 알코올 발효는 Saccharomyces cerevisiae YM33 균주를 보리쌀에 접종하여 제조한 주모를 혼합하여 $25^{\circ} \mathrm{C}$ 에서 진행하여 $11 \%$ 알코올 함량을 갖는 보리 술을 제조하였다. 마지막으로 초산발효는 여과한 맑은 보리 술에 창포분말, 누룩, Acetobacter pasteurianus A11-2를 포 함한 종초를 혼합하여 $30^{\circ} \mathrm{C}$ 에서 10 일간 정치발효하여 $\mathrm{pH}$ 3.48 , 산도 $4.44 \%$ 의 품질특성을 갖는 창포식초를 제조하였 다. 창포뿌리를 함유한 창포식초는 종초 첨가에 따라 발효 15 일 차에 $870.13 \mathrm{mg} \mathrm{TAE} / \mathrm{mL}$ 로 가장 높은 총 페놀 함량을 나타내었고, DPPH radical 및 $\mathrm{ABTS}^{+}$radical 소거 활성도 종 초 무첨가군과 비교하여 높은 항산화능을 나타났다. 또한 창 포식초 중 향기성분은 보리술에서 높았던 ethanol, 3-methyl1-butanol, 2-methyl-1-propanol은 초산발효가 진행됨에 따라 감소한 반면, 민트향을 가지는 methyl salicylate와 달콤한 꽃 향기를 내는 2-ethylhexanol은 조금 높게 검출되었다. 결론적 으로 발효종균으로 제조한 누룩과 보리술을 이용하여 만든 창포식초는 항산화 활성과 독특한 향기성분을 포함하고 있어 발효식초 자체의 음용뿐만 아니라, 이미용 소재로도 이용 가 능할 것으로 기대된다.

\section{감사의 글}

이번 연구는 농촌진흥청 농업기초기반연구사업(PJ013418) 의 지원에 의해 수행된 것으로 이에 감사드립니다.

\section{Conflict of interests}

The authors declare no potential conflict of interest.

\section{ORCID}

Na-Young Gil https://orcid.org/0000-0002-6925-2498

So-Young Kim https://orcid.org/0000-0002-9729-6869

\section{References}

Baek CH, Jeong DH, Baek SY, Choi JH, Park HY, Choi HS, Jeong ST, Kim JH, Jeong YJ, Kwon JH, Yeo SH. Quality characteristics of farm-made brown rice vinegar via traditional static fermentation. Korean $\mathrm{J}$ Food Preserv, 20, 564-572 (2013)

Baek SY, Lee YJ, Kim MD, Yi JH, Mun JY, Yeo SH. Characterization of ethanol fermentation with wild type yeast strains. Microbial Biotechnol Lett, 43, 227-235 (2015)

Chen T, Gui Q, Shi JJ, Zhang XY, Chen FS. Analysis of variation of main components during aging process of Shanxi aged vinegar. Acetic Acid Bacteria, 2, 31-38 (2013)

Cho HD, Kim JH, Lee JH, Hong SM, Yee ST, Seo KI. Anti-fatigue effect of a cucumber vinegar beverage on rats after high-intensity exercise. Korean J Food Sci Technol, 49, 209-214 (2017)

Cho JW, Kim IS, Kim MK, Lee YK, Kim SD. Characteristics of peach vinegar by parallel complex fermentation. Korean J Postharvest Sci Technol, 7, 89-93 (2000)

Choi GY, Ko BS, Lee MY, Chae SW, Kim YH, Ryuk JA, Baek JS, Lee HW. Comparative study of Changpo species on antioxidant activity and HPLC pattern analysis. Korea J Herbology, 26, 13-19 (2011)

Choi HS. Characteristic impact odorants of changpo (Acorus calamus var. angustatus Bess) root essential oil. Food Sci Biotechnol, 14, 450-455 (2005)

Choi YH, Choi DH, Park EH, Kim MD. Isolation of potent amylolytic fungus Rhizopus oryzae from Nuruk. Microbiol Biotechnol Lett, 44, 376-382 (2016)

Danner GR, Muto KW, Zieba AM, Stillman CM, Seggio JA, Ahmad ST. Spearmint (l-carvone) oil and wintergreen (methyl salicylate) oil emulsion is an effective immersion anesthetic of fishes. J Fish Wildlife Management, 2, 146-155 (2011)

Gil NY, Gwon HM, Yeo SH, Kim SY. Metabolite profile and immunomodulatory properties of bellflower root vinegar produced using Acetobacter pasteurianus A11-2. Foods, 9, 1063 (2020)

Han EH, Lee TS, Noh BS, Lee DS. Quality characteristics in mash Takju prepared by using different Nuruk during fermentation. Korea J Food Sci Technol, 29, 555-562 (1997)

Heo BG, Park YS, Yoo YK, Han TH, Park YJ, Sin JS, Cho JY. In vitro assay on biological characteristics of different extracts from Acorus calamus L. var angustatus. Flower Res J, 16, 168-173 (2008)

Hwang MY. Quality characteristics of Takju prepared by blended starchy materials. MS Thesis, Seoul Woman's University, Korea, p 13-15 (2002) 
Hwang MS. Hair protective effect of water extracts from Acorus calamus leaf. MS Thesis, Catholic University of Daegu, Korea, p 15-23 (2004)

Jung HK, Kim YJ, Park BK, Park SC, Jeong YS, Hong JH. Antioxidative and antimicrobial activities of medicinal plant extracts for screening phytobiotic material. J Korean Soc Food Sci Nutr, 36, 1235-1240 (2007)

Kim HJ, Kim SW, Shin CS. Analysis of chemical composition in leaf and root of Acrorus calamus L.. Korean J Food Sci Technol, 32, 37-41 (2000)

Kim YS, Baek DJ. The study on characteristics of dyeing hair with Hwangtoh and iris extract. Korean Society Environmental Analysis, 11, 83-90 (2008)

Lee EK, Kwon WY, Lee JW, Yoon JA, Chung KH, Song BC, An JH. Quality characteristics and antioxidant activity of vinegar supplemented added with Akebia quinata fruit during fermentation. J Korean Soc Food Sci Nutr, 43, 1217-1227 (2014)

Lee JA, Lee SH, Park YS. Optimization of fermentation condition for onion vinegar using Acetobacter orientalis MAK88. Food Eng Prog, 403-408 (2017)

Lee YJ, Ahn YH, Seo WT. Carrot vinegar fermentation by independent two-step fermentation process and its physiochemical characteristics. J Agric Life Sci, 50, 151-164 (2016)
Mohamad NE, Yeap SK, Ky H, Ho WY, Boo SY, Chua J, Beh BK, Sharifuddin SA, Long K, Alitheen NB. Dietary coconut water vinegar for improvement of obesityassociated inflammation in high-fat-diet-treated mice. Food Nutr Res, 61, 1368322 (2017)

Pang TS, Lee KJ, Ham IH, Bu YM, Kim HC, Rhee JS, Choi HY. A study on the content changes of $\beta$-asarone and $\alpha$-asarone in Acorus gramineus according to its parts, extraction solvent, and fermentation. Kor J Herbology, 23, 149-157 (2008)

Park EH, Choi CY, Kwon HJ, Kim MD. Literature review on type and manufacturing methods of Korean traditional vinegar. Food Science and Industry, 49, 94-99 (2016)

Park YO. Quality characteristics of fermented vinegars using pear. Korean J Food Preserv, 23, 778-787 (2016)

Sakanaka S, Ishihara Y. Comparison of antioxidant properties of persimmon vinegar and some other commercial vinegars in radical-scavenging assays and on lipid oxidation in tuna homogenates. Food Chem, 107, 739-744 (2008)

Yim EJ, Jo SW, Lee ES, Park HS, Ryu MS, Uhm TB, Kim HY, Cho SH. Fermentation characteristics of mulberry (Cudrania tricuspidata) fruit vinegar produced by acetic acid bacteria isolated from traditional fermented foods. Korean J Food Preserv, 22, 108-118 (2015) 